\title{
Guest editorial-special issue on ground control in mining in 2018
}

\author{
Michael M. Murphy \\ NIOSH, Pittsburgh, PA \\ Ted Klemetti \\ NIOSH, Pittsburgh, PA \\ Heather Lawson \\ NIOSH, Spokane, WA \\ Brijes Mishra \\ West Virginia University \\ Kyle Perry \\ Missouri S\&T
}

Follow this and additional works at: https://researchrepository.wvu.edu/faculty_publications

\section{Digital Commons Citation}

Murphy, Michael M.; Klemetti, Ted; Lawson, Heather; Mishra, Brijes; and Perry, Kyle, "Guest editorial-special issue on ground control in mining in 2018" (2019). Faculty \& Staff Scholarship. 2501. https://researchrepository.wvu.edu/faculty_publications/2501

This Article is brought to you for free and open access by The Research Repository @ WVU. It has been accepted for inclusion in Faculty \& Staff Scholarship by an authorized administrator of The Research Repository @ WVU. For more information, please contact beau.smith@mail.wvu.edu. 


\title{
Guest editorial-special issue on ground control in mining in 2018
}

\author{
Michael M. Murphy ${ }^{\mathrm{a}, *}$, Ted Klemetti ${ }^{\mathrm{a}}$, Heather Lawson ${ }^{\mathrm{b}}$, Brijes Mishra ${ }^{\mathrm{c}}$, Kyle Perry ${ }^{\mathrm{d}}$ \\ a Pittsburgh Mining Research Division, NIOSH, Pittsburgh, PA 15228, USA \\ ${ }^{\mathrm{b}}$ Spokane Mining Research Division, NIOSH, Spokane, WA 99207, USA \\ 'Mining Engineering, West Virginia University, Morgantown, WV 26506, USA \\ ${ }^{\mathrm{d}}$ Mining \& Nuclear Engineering, Missouri SET, Rolla, MO 65409, USA
}

Ground control is the science of studying and controlling the behavior of rock strata in response to mining operations. Ground control-related research has seen significant advancements over the last 37 years, and these accomplishments are well documented in the proceedings of the annual International Conference on Ground Control in Mining (ICGCM) [1]. The ICGCM is a forum to promote closer communication among researchers, consultants, regulators, manufacturers, and mine operators to expedite solutions to ground control problems in mining [2-6]. Fundamental research and advancements in ground control science define the central core of the conference mission. Providing information to mine operators is a priority, as the conference goal is to offer solutions-oriented information. In addition, the conference has included innovative technologies and ideas in mining-related fields such as exploration, geology, and surface and underground mining. Many new ground control technologies and design standards adopted by the mining industry were first discussed at ICGCM. Therefore, this conference is recognized as the best international forum for introducing new ground control-related research and products.

Professor Syd Peng (West Virginia University), on his own initiative, organized the First Conference on Ground Control in Mining in the summer of 1981. Dr. Peng keenly recognized that in order to advance the state-of-the-art in ground control, a forum was urgently needed whereby researchers, practitioners, equipment manufacturers, and government regulators could meet regularly and exchange information in a timely manner. Beginning in 2016, the conference was taken over by the Society for Mining, Metallurgy \& Exploration (SME). Four researchers, Brijes Mishra (West Virginia University), Kyle Perry (Missouri University of Science and Technology), Heather Lawson (NIOSH), and Michael Murphy (NIOSH), were chosen to serve as a secondary team from the conference's organizing committee to ensure that the ICGCM continues to advance the science of evasive ground control problems and develop solutions through current mine design strategies, operational practices, and engineering interventions. Ted Klemetti

\footnotetext{
Received 05 June 2018; Revised 28 July 2018; Accepted 26 August 2018.

* Corresponding author.

E-mail address: mmu5@cdc.gov (M.M. Murphy).
}

(NIOSH) was added to the team in 2017 and will serve as the conference chair for the 38th and 39th conferences.

The 37th International Conference on Ground Control in Mining was held on July 24-26, 2018, in Morgantown, WV. This year's event had 171 attendees with significant representation from government researchers, academia, and mine operators. The event included 47 papers in 10 different sessions during the three days of the conference. The international community was represented with 28 attendees from five countries, with China sending fourteen representatives and Australia sending eight. In addition to an increased presence from the coal industry compared to last year, attendees from the potash, salt, and hard rock industries were also represented.

The topics covered at this year's conference included a wide range of subjects including pillar design and evaluation, case histories, roof control, subsidence research, and presentations showcasing new ground control software and product development. Dr. Christopher Mark (MSHA) and Dr. Zach Agioutantis (University of Kentucky) opened up the conference and presented on Analysis of Coal Pillar Stability (ACPS): A New Generation of Pillar Design Software. Thirty years ago, the Analysis of Longwall Pillar Stability (ALPS) inaugurated a new era in coal pillar design. ALPS was the first empirical pillar design technique to incorporate the abutment loads that arise in retreat mining, and to be calibrated to an extensive database of longwall case histories. ALPS was followed by the Analysis of Retreat Mining Stability (ARMPS) and the Analysis of Multiple Seam Stability (AMSS). This presentation highlighted that the ACPS software now integrates all three of the older packages into a single pillar design framework. ACPS also incorporates the latest research findings in the field of pillar design, including an expanded multiple seam case history database, a new method to evaluate room and pillar panels containing multiple rows of bleeder pillars, and a formula for calculating the strength of unusually shaped pillars. The presentation was followed by a presentation by Russell Frith (Mine Advice Pty Ltd.), who offered a rebuttal and discussed The Limitations and Potential Design Risks When Applying Empirically-Derived Coal Pillar Strength Equations to Real-Life Mine Stability Problems. This presentation explored the reasons as to why empirically-derived coal pillar strength equations tend to be problem-specific, and so should perhaps be considered as providing no more than a pillar strength "index". 
These equations include the non-consideration of overburden horizontal stress within the mine stability problem, an inadequate definition of super-critical overburden behaviour as it applies to coal pillar loading, and the non-consideration of overburden displacement and coal pillar strain limits, all of which combine to potentially complicate and thus confuse the back-analysis of coal pillar strength from failed cases.

Case histories and roof control research were also highlighted during the first day of the conference. Jun Lu (CONSOL Energy) presented research on the Challenges of Mining the First RightHanded Longwall in the Pittsburgh Seam. The objective of the research was to further understand the impact of the right-handed and left-handed longwall panel in the longwall headgate. In addition, the impact of other geologic factors, such as large overburden, poor roof geology, soft floor, and large headgate equipment were also analyzed. Daniel Su (NIOSH) presented research becoming increasingly relevant to the shale gas industry, titled "Effect of Longwall-induced Subsurface Deformations on Shale Gas Well Casing Stability under Deep Cover". Due to the recent shale gas boom, approximately 5000 conventional and unconventional gas wells have been drilled ahead of longwall mining in Pennsylvania, West Virginia, and Ohio. These shale gas wells will remain active over the next 40 to 50 years. Longwall-induced subsurface overburden deformations may, in some cases, compromise the mechanical integrity of shale gas well casings. This presentation discussed a very important step and initiative in utilizing the knowledge and science obtained from mining research to improve miner and public safety as well as the safety and health of the workers in the oil and gas industries. Meriel Young (Colorado School of Mines) revisited past research that had first been introduced at ICGCM over 20 years ago with a presentation titled, "What factors over and above those included in the existing Coal Mine Roof Rating (CMRR) could also be predictive of roof instability in underground coal mines?" The CMRR has been widely used and validated in Eastern US coal mines, but has seen limited application in the Western US. Based on two Western coal mine case studies, Ms. Young hypothesized that there are other factors that are correlated with roof instability in underground coal mines that could potentially also be included in the CMRR, to make it more comprehensive in explaining roof instability.

The conference also included an increased number of presentations from topics outside of the coal industry. Jay Nopola (RESPEC) presented Considerations for Effective Ground Support in
Evaporites, which highlighted the unique ground control problems in mining commodities such as salt and potash. Evaporites are subject to continual creep and no amount of ground support can successfully arrest this process. Common ground support techniques that are useful for many different rock types can reduce the effective life of bolts in evaporites and create unseen hazards. During the presentation, a different approach to ground support was highlighted to include long-term support strategies in areas where high creep rates are present. Robert Eades (Missouri University of Science and Technology) presented Understanding The Connection Between Blasting and Highwall Stability, which summarized a survey and discussion of advantages and disadvantages, as well as necessary requirements, for successful incorporation of controlled blasting techniques into highwall ground control plans. Juan Monsalve (Virginia Tech) presented Application of Laser Scanning for Rock Mass Characterization and Discrete Fracture Network Generation in an Underground Limestone Mine. The presentation highlighted the success of processing laser scan point clouds to generate discrete fracture networks for further discontinuous modeling.

A number of the papers, including the ones discussed above from the 37th International Conference on Ground Control in Mining, are included in this special issue of the International Journal of Mining Science and Technology. All other papers from this year's conference (and conferences from previous years) can be found on the ICGCM website (http://groundcontrolmining.com/) and at OneMine (http://www.onemine.org/). We hope this special issue will provide useful references for engineers worldwide and for researchers and scholars in the field of ground control.

\section{References}

[1] ICGCM website that stores all 37 conference proceedings since 1981 for free distribution: http://groundcontrolmining.com/.

[2] Peng SS. Topical areas of research needs in ground control: a state of the art review on coal mine ground control. Int J Min Sci Technol 2015;25(1):1-6.

[3] Peng SS. Coal mine ground control. 3rd ed. Morgantown: Syd Peng Publisher; 2008.

[4] Peng SS. Ground control failures. Morgantown: Syd Peng Publisher; 2007.

[5] Heasley KA, Su DWH. 25 years of progressive in numerical modeling for ground control-What have we accomplished and where do we go next? In: Proceedings of the 25th international conference on ground control in mining. Morgantown. p. 11-7.

[6] Hasenfus GJ, Su DWH. Horizontal stress and coal mines: twenty five years of experience and perspective. In: Proceedings of the 25th international conference on ground control in mining. Morgantown. p. 256-67. 